\title{
Biological Nitrogen Fixation in Production of Vigna unguiculata (L.) Walp, Family Farming in Piauí, Brazil
}

\author{
Linnajara de Vasconcelos Martins Ferreira ${ }^{1}$, Rafaela Simão Abrahão Nóbrega ${ }^{1}$, Júlio César Azevedo Nóbrega ${ }^{1}$, \\ Flávia Louzeiro de Aguiar ${ }^{1}$, Fatima Maria de Souza Moreira ${ }^{3} \&$ Leandro Pereira Pacheco ${ }^{2}$ \\ ${ }^{1}$ Federal University of Piauí, Brazil \\ ${ }^{2}$ Federal University of Mato Grosso, Brazil \\ ${ }^{3}$ Lavras Federal University, Brazil
}

Correspondence: Leandro Pereira Pacheco, Federal University of Mato Grosso, Brazil. E-mail: leandroppacheco@gmail.com

Received: January 14, 2013 Accepted: February 25, 2013 Online Published: March 15, 2013

doi:10.5539/jas.v5n4p153 URL: http://dx.doi.org/10.5539/jas.v5n4p153

\begin{abstract}
Although inoculation of $\mathrm{N}_{2}$-fixing bacteria in cowpea is important, there are no studies on their performance in Itaueira, PI, Brazil. This work aimed to evaluate the symbiotic efficiency of nodulating bacteria strains officially approved by Ministério da Agricultura, Pecuária e Abastecimento, Brazil - MAPA (INPA 3-11B, UFLA 3-84, BR 3267 and BR 3262) and in phase of selection (UFLA 3-164 and UFLA 3-154) in the nodulation and growth of cowpea cultivar BR 17 Gurguéia in Itaueira, PI, Brazil. Experimental design was in randomized blocks with eight treatments and four replications, consisting of six strains cited and two non inoculated controls, one with $\mathrm{N}$ mineral $\left(70 \mathrm{~kg} \mathrm{ha}^{-1}\right.$ of $\left.\mathrm{N}\right)$ and other without $\mathrm{N}$ mineral. Nodulation, growth, yield and accumulation of $\mathrm{N}, \mathrm{P}, \mathrm{K}, \mathrm{Ca}$ and $\mathrm{Mg}$ in shoots of cowpea beans were evaluated. Strains under test phase (UFLA 3-154 and UFLA 3-164) presented number of nodules, and fresh and dry biomass of nodules similar to strains currently approved as inoculants. Treatments inoculated with INPA 3-11B and BR 3267 strains were more efficient in dry biomass production of shoots. Plants inoculated with strains UFLA 3-164, INPA 3-11B and BR 3267 presented highest concentration of N, P, K, Ca, and Mg in dry biomass of shoots. Strains in selection phase (UFLA 3-164 and UFLA 3-154) presented similar grain yield among themselves, however the strain UFLA 3-154 obtained productivity equivalent to the nitrogen control and all strains evaluated. Inoculation of cowpea with strains BR 3262, BR 3267 and UFLA 3-154 promoted increments of cowpea productivity in Itaueira, PI, therefore they may be recommended for cultivation in this region.
\end{abstract}

Keywords: cowpea, biological nitrogen fixing, macronutrients

\section{Introduction}

In Brazil, the cultivation of cowpea (Vigna unguiculata (L.) Walp.) is concentrated mainly in the North and Northeast, where almost all production comes from rainfed conditions. The country is the third largest producer of this crop, with an acreage of more than 1.6 million hectares (Instituto Brasileiro de Geografia e Estatística [IBGE], 2006), but has low productivity, around $300-400 \mathrm{~kg} \mathrm{ha}^{-1}$.

In the municipality of Itaueira, located in the Southwest of Piauí State, Brazil, the cowpea is grown predominantly by small farmers without adopting low technology, for food and income. The average yield in this city is far below the national average, standing at around $180 \mathrm{~kg} \mathrm{ha}^{-1}$, which indicates the need to use practices that enable increases in productivity, environmentally and economically sustainable way. Among the technologies that can enable increases in grain yield, highlights the biological nitrogen fixation (BNF). In addition to minimizing the cost of production by reduction of nitrogen fertilizer use, this technology has benefits for the environment and promotes increases fertility and soil organic matter (Soares et al., 2006).

Work developed in the state of Piauí with cowpea has shown significant increase of grain yield with use of inoculants of bacteria nodulating legumes (BNL) through the process of BNF (Costa et al., 2011; Almeida et al., 2010). Costa et al. (2011) observed an increase in grain yield of cowpea BR 17 Gurguéia Pole production of municipal district of Bom Jesus, PI, inoculated with strains INPA 3-11B and UFLA 3-154. These provided a yield of $1223 \mathrm{~kg} \mathrm{ha}^{-1}$ and $1016 \mathrm{~kg} \mathrm{ha}^{-1}$, respectively, and these treatments to equal treatment with nitrogen $\left(70 \mathrm{~kg} \mathrm{~N} \mathrm{ha}^{-1}\right)$, 
which gave a yield of $1605 \mathrm{~kg} \mathrm{ha}^{-1}$. Almeida et al. (2010), trial conducted in the city of Teresina, PI, using cowpea cultivar BR 17 Gurguéia found grain yield of $1637 \mathrm{~kg} \mathrm{ha}^{-1}$ to BR 3267, of $1,823 \mathrm{~kg} \mathrm{ha}^{-1}$ to BR 3262, and $1945 \mathrm{~kg}$ $\mathrm{ha}^{-1}$ to the INPA $3-11 \mathrm{~B}$, promoting an increase of $25 \%, 39 \%$ and $50 \%$, respectively, compared to the control without $\mathrm{N}$ and uninoculated.

Although inoculation of $\mathrm{N}_{2}$-fixing bacteria in cowpea is important, there are no studies on their performance in management conditions used in family farming in Itaueira, PI. In this context the objective of this study was to evaluate the agronomic efficiency of rhizobia strains approved and pending approval by the Ministerio da Agricultura, Pecuária e Abastecimento (MAPA) for inoculation in the field, using the cowpea cultivar BR 17 Gurguéia the municipal district of Itaueira, Piauí State, Brazil.

\section{Materials and Methods}

The test was conducted in the municipal district of Itaueira, Altos farm $\left(07^{\circ} 36^{\prime} 10^{\prime \prime}\right.$ South latitude, $43^{\circ} 01^{\prime} 33^{\prime \prime}$ west longitude and altitude of $258 \mathrm{~m}$ ) in the period from February to May 2012, in the oxissol with medium texture in the area without prior use of any type of inoculant. The monthly precipitation and temperature during the experimental period, according Inmet, are described in Figure 1.

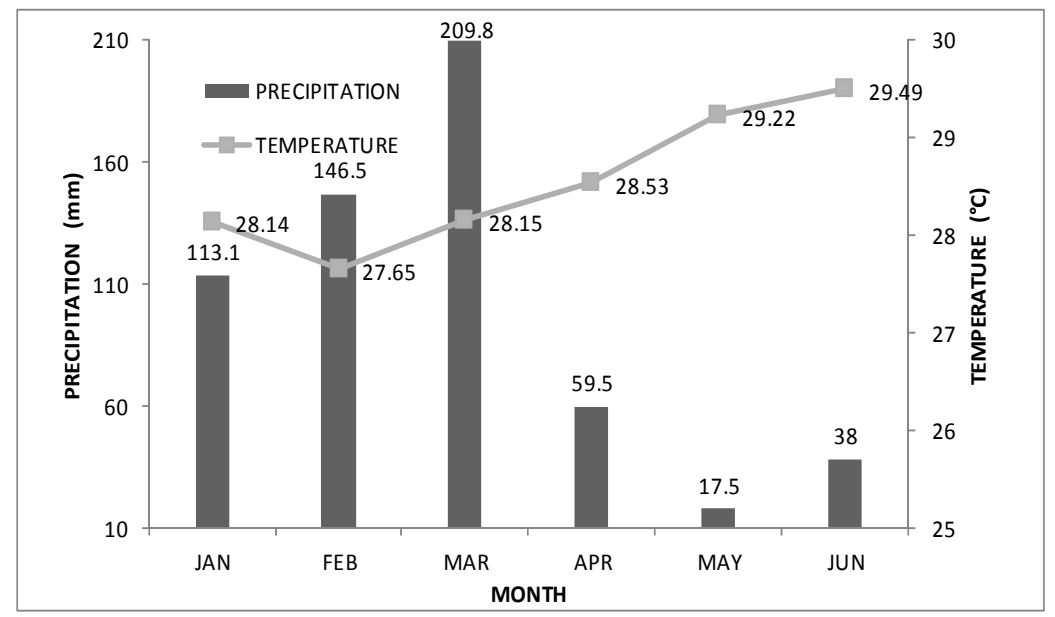

Figure 1. Precipitation between the months of January to June 2011, in the municipal district of Itaueira, PI, Brazil

The soil chemical characteristics assessed in the layer of 0 to $0.2 \mathrm{~m}$ were: $\mathrm{pH}$ in $\mathrm{H}_{2} \mathrm{O}$ (1:2.5) 5.4; $\mathrm{P}$ (Mehlich 1$) 2.9$ $\mathrm{mg} \mathrm{dm}{ }^{-3} ; \mathrm{K}^{+} 0.15 \mathrm{cmol}_{\mathrm{c}} \mathrm{dm}^{-3} ; \mathrm{Ca}^{2+} 0.6 \mathrm{cmol}_{\mathrm{c}} \mathrm{dm}^{-3} ; \mathrm{Mg}^{2+} 0.3 \mathrm{cmolc} \mathrm{dm}^{-3} ; \mathrm{Al}^{3+} 0.2 \mathrm{cmol}_{\mathrm{c}} \mathrm{dm}^{-3} ; \mathrm{H}+\mathrm{Al} 1,9 \mathrm{cmol}_{\mathrm{c}} \mathrm{dm}^{-3}$; SB $1.1 \mathrm{cmol}_{\mathrm{c}} \mathrm{dm}^{-3}$; Effective CEC $1.3 \mathrm{cmol}_{\mathrm{c}} \mathrm{dm}^{-3}$; Potential CEC $2.9 \mathrm{cmol}_{\mathrm{c}} \mathrm{dm}^{-3} ; \mathrm{m} \mathrm{15.9 \%}$; V 36.3\%; organic

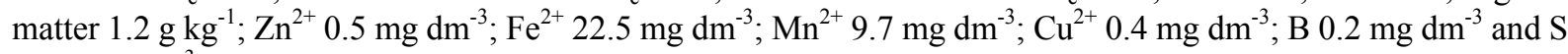
$37.2 \mathrm{mg} \mathrm{dm}^{-3}$.

The cowpea cultivar selected for this study was BR 17 Gurguéia for being the most widely grown and marketed in the region of Itaueira, PI. The experimental design was a randomized block design with four replications and eight treatments (ways of adding N), consisting of: four strains of nitrogen-fixing bacteria approved by MAPA as inoculant for cowpea, INPA 3-11B, UFLA 3-84, both isolated from Amazonian soils and identified as belonging to the genus, Bradyrhizobium (Lacerda et al., 2004; Soares et al., 2006) BR 3267, originated from the culture collection of Embrapa Agrobiologia (Martins et al., 2003), BR 3262 arising from the collection of Embrapa Roraima, also belonging to the genus Bradyrhizobiume two strains under selection: UFLA 3-164 and UFLA 3-154 (isolated from soil bauxite mining rehabilitation (Melloni et al., 2006) and assessed for their effectiveness in pots like Leonard with nutrient solution and vermiculite (Motta, 2002) and in the field by Costa et al. (2011), and two witnesses: a nitrogen with $70 \mathrm{~kg} \mathrm{~N} \mathrm{ha}^{-1}$, urea source, as recommended by Freire Filho et al. (2007) and one without inoculation and without mineral N. Nitrogen fertilization was split in two equal doses, one at planting and another 20 days after emergence of plants.

The soil was prepared with plowing and disking. Seeking to maintain the conditions of crop management in the region, no use fertilizer or soil fertilization.

The inoculant was prepared with autoclaved peat, in the ratio 3:1 (peat: culture) in culture "79" semi-solid (Waksman \& Fred, 1928) in log phase (after five days of growth with minimal concentration of $10^{9} \mathrm{cells} \mathrm{g}^{-1}$ 
inoculant). Seeds were inoculated with $500 \mathrm{~g}$ of inoculant per $50 \mathrm{~kg}$ seed. Sowing was done immediately after inoculation, sowing up four seeds per hole at a spacing of $1.0 \times 0.20 \mathrm{~m}$. Thinning was performed at 15 days after planting, leaving two plants per hole.

The plots consisted of four rows of $6 \mathrm{~m}$ length, spaced $1.0 \mathrm{~m}$, totaling $24 \mathrm{~m}^{2}$ of total area, with the floor area of the two central lines. The cultivation was conducted under rainfed-regime. During the conduct of the assay were performed manual and mechanical weeding with the use of hoes, maintaining the culture free from weeds.

In the first evaluation performed during flowering at 45 days after planting were randomly collected from ten plants per plot for evaluation of number of nodules per plant $(\mathrm{NN})$ and fresh and dry biomass of nodules (FBN and DBN), dry biomass of shoot (DBS) and relative efficiency (REEF). After weighing, the shoot was triturated for determination of $\mathrm{N}$ content by distiller Kjeldahl method (Liao, 1981), phosphorus extracted by colorimeter metavanadate, potassium, obtained from emission flame photometry, calcium and magnesium determined following the method of quelatermetry EDTA (Malavolta et al., 1997).

The second assessment at harvest was performed 84 days after sowing, and the pods were collected manually from 10 plants of the useful area of each plot. Thereafter, all the pods were air dried and threshed for assessing the number of pods per plant (NPPL), biomass of pods per plant (BPPL) and grain yield per hectare (GY). After weighing the grains were ground for determining the $\mathrm{N}$ content in grains by the distiller Kjeldahl method (Liao, 1981).

To determine the dry biomass of shoot, the material was packed in paper bags and placed in a forced air oven at $65^{\circ} \mathrm{C}$ until constant weight. The relative efficiency of each strain was calculated as follows:

REEF $=($ DBS inoculated $) * 100 /($ DBS plant fertilized with mineral $N)$

To evaluate the grain yield, its moisture was corrected to $13 \%$ wet basis. The accumulation of nutrients in grains and leaves were calculated by multiplying the:

Dry biomass of shoot $(\mathrm{g})$ or grain * (\% nutrient content) / 100

The test data were subjected to analysis of variance using the Statistical Analysis System SISVAR, version 4.2 (Ferreira, 2000). The effects of the treatments were compared by Tukey test at 5\% probability.

\section{Results and Discussion}

In the first evaluation, conducted during flowering, there was a significant effect of the forms of $\mathrm{N}$ supply on the NN, FBN, DBN, DBS and REEF (Table 1).

Table 1. Average number of nodules per plant (NN), fresh (FBN) and dry (DBN) of nodules, dry biomass of shoot (DBS), relative efficiency (REEF) of Vigna unguiculata (L.) Walp, for different forms of $\mathrm{N}$ supply during flowering (45 days after seeding)

\begin{tabular}{|c|c|c|c|c|c|}
\hline \multirow[t]{2}{*}{$\mathrm{N}$ sources } & \multirow{2}{*}{$\begin{array}{c}\mathrm{NN} \\
\text { Number nodules }\end{array}$} & FBN & $\mathrm{DBN}$ & DBS & \multirow{2}{*}{$\begin{array}{c}\text { REEF } \\
\%\end{array}$} \\
\hline & & & g plant $^{-1}$ & & \\
\hline TEST CN- $70 \mathrm{~kg} \mathrm{ha}{ }^{-1}$ & $0.350 \mathrm{~d}$ & $0.045 \mathrm{~b}$ & $0.031 \mathrm{~d}$ & $10.656 \mathrm{a}$ & $100.00 \mathrm{a}$ \\
\hline TEST SN & $2.025 \mathrm{~d}$ & $0.421 \mathrm{~b}$ & $0.107 \mathrm{~d}$ & $4.782 \mathrm{~b}$ & $45.209 \mathrm{~b}$ \\
\hline UFLA 3-84 & $9.737 \mathrm{c}$ & $5.402 \mathrm{a}$ & $0.544 \mathrm{~cd}$ & $6.270 \mathrm{~b}$ & $59.355 \mathrm{~b}$ \\
\hline BR 3262 & $10.232 \mathrm{c}$ & $4.902 \mathrm{a}$ & $0.670 \mathrm{cb}$ & $5.862 \mathrm{~b}$ & $55.437 \mathrm{~b}$ \\
\hline UFLA 3-164 & $9.710 \mathrm{c}$ & $5.674 \mathrm{a}$ & $0.671 \mathrm{cb}$ & $6.299 \mathrm{~b}$ & $59.736 \mathrm{~b}$ \\
\hline UFLA 3-154 & $12.105 \mathrm{bc}$ & $4.679 \mathrm{a}$ & $1.072 \mathrm{ab}$ & $6.737 \mathrm{~b}$ & $62.858 \mathrm{~b}$ \\
\hline BR 3267 & $16.225 \mathrm{a}$ & $6.530 \mathrm{a}$ & $1.274 \mathrm{a}$ & $9.574 \mathrm{a}$ & $90.800 \mathrm{a}$ \\
\hline INPA 3-11B & $15.217 \mathrm{ab}$ & $6.905 \mathrm{a}$ & $1.199 \mathrm{a}$ & $9.410 \mathrm{a}$ & $88.948 \mathrm{a}$ \\
\hline \multicolumn{6}{|l|}{ Variation Sources } \\
\hline F value & $65.860^{*}$ & $28.967 *$ & $17.983^{*}$ & $15.088^{*}$ & $15.605^{*}$ \\
\hline Treatment (DF) & 7 & 7 & 7 & 7 & 7 \\
\hline Block (DF) & 3 & 3 & 3 & 3 & 3 \\
\hline Error (DF) & 21 & 21 & 21 & 21 & 21 \\
\hline QMR & 1.95 & 0.95 & 0.04 & 1.19 & 102.06 \\
\hline LSD & 3.314 & 2.32 & 0.52 & 2.59 & 23.96 \\
\hline CV (\%) & 14.78 & 22.65 & 31.79 & 14.62 & 14.37 \\
\hline
\end{tabular}

* Significant $5 \%$ probability by Tukey test, $\mathrm{DF}=$ degree of freedom, mean square residual $=\mathrm{QMR}, \mathrm{LSD}=$ least significant difference, $\mathrm{CV}=$ coefficient of variation. Means followed by the same letter in columns do not differ according to the Tukey test at $5 \%$ probability. 
For the variable NN, treatments inoculated with strains BR 3267 and INPA 3-11B had higher averages. The number of nodules are in the range found by other authors in the Northeast of Brazil (Almeida et al., 2010; Costa et al., 2011), but lower than those found in the Southeast, State of Minas Gerais, Brazil (Lacerda et al., 2004; Soares et al., 2006). However, it should be noted that these experiments were fertilized with phosphate $\left(70 \mathrm{~kg} \mathrm{P}_{2} \mathrm{O}_{5} \mathrm{ha}^{-1}\right)$ and potassium $\left(40 \mathrm{~kg} \mathrm{~K}_{2} \mathrm{O} \mathrm{ha}^{-1}\right)$. Among the treatments inoculated strains under selection (UFLA 3-154 and UFLA 3-164) NN showed similar and equal to those inoculated with strains UFLA 3-84 and BR 3262, and UFLA 3-154 not differ significantly from INPA 3-11B. Results were checked against by Costa et al. (2011), when evaluating the agronomic efficiency of symbiotic diazotrophs strains under selection (UFLA 3-154 and UFLA 3-164) as well as the currently approved as inoculants by MAPA (BR 3267, UFLA -384, INPA 3-11B), Pole Production of Bom Jesus, PI, in some oxisol fertilized observed that the strains studied as NN did not differ $(p<0.05)$. The experiment was conducted in a traditional area of cultivation cowpea, although this culture is considered promiscuous (Guimarães et al., 2012; Lima et al., 2005; Melloni et al., 2006) the untreated and mineral N without inoculation and also the witness nitrogen provided the lowest values of $\mathrm{NN}$, differing significantly inoculated treatments.

Regarding variables FBN and DBN, the strains being promoted similar results to the selection of strains currently approved as inoculum (UFLA 3-84, INPA 3-11B, BR 3262 and BR 3267). The strain UFLA 3-154 stood out by not differ significantly from strains INPA 11B and 3-BR 3267 that promoted higher values of NFM and DBN. The witness nitrogen $\left(70 \mathrm{~kg} \mathrm{~N} \mathrm{ha}^{-1}\right)$ and control without the addition of mineral $\mathrm{N}$ had similar values as the FBN and DBN, represented the lowest averages for these variables. Almeida et al. (2010) found similar results for N-control to check that the DBN control treatment with mineral fertilizer of $80 \mathrm{~kg} \mathrm{~N}^{-1}$ was reduced, as well as the control treatment with $50 \mathrm{~kg} \mathrm{~N} \mathrm{ha}^{-1}$ in comparison to inoculated treatments, indicating the inhibitory effect of nitrogen on DBN. This effect has also been reported by several authors (Costa et al., 2010; Martins et al., (in press); Soares et al., 2006).

As for the DBS and REEF superior results were observed for the strains BR 3267, INPA 3-11B and the treatment with $70 \mathrm{~kg} \mathrm{~N} \mathrm{ha}^{-1}$ compared to control without addition of mineral $\mathrm{N}$ and the other inoculated treatments (Table 1). Guedes et al. (2010), found differences in all inoculated treatments compared to absolute control without N. Strains in the selection phase and obtained mean of DBS and REEF lower compared to strains BR 3267 and INPA 3-11B, but similar to strains UFLA 3-84, BR 3262 and without N mineral. Costa et al. (2011), in a field trial in the Polo production of Bom Jesus, PI, located $300 \mathrm{~km}$ from the municipal district of Itaueira, PI, noticed that for DBS and REEF no significant difference between treatments inoculated and control without $\mathrm{N}$. The strain UFLA 3-154 (selection phase) stood out, promoting REEF of $75.4 \%$, significantly equal to $\mathrm{N}$-control. The lack of difference between the treatment without mineral $\mathrm{N}$ and inoculated treatments proved the ability of the native population to establish symbiosis with cowpea when grown in the Polo production of Bom Jesus, PI without the use of inoculants.

Another factor that can directly affect the symbiosis is the occurrence of water deficiencies, with negative effect, especially during flowering and pod filling (Calvache \& Reichardt, 1996), besides affecting the survival of rhizobia in the soil. How the test was conducted under rainfed and without application of fertilizer, under conditions of small producers, the differences between the DBS and REEF strains BR 3267 and INPA 3-11B compared to other strains studied, show the high ability of these strains in the production of plant biomass.

Plants inoculated with the strains UFLA 3-164, IMPA 3-11B and BR 3267 presented the highest concentrations of $\mathrm{N}, \mathrm{P}, \mathrm{K}, \mathrm{Ca}$, and Mg in the DBS except BR 3262 that presented lower accumulation of K (Table 2). In literature there are few works that study the response of the accumulation of macronutrients in dry biomass of shoot of cowpea due to the inoculation, with the exception of $\mathrm{N}$. To $\mathrm{N}$ accumulation in shoot Almeida et al. (2010) observed no differences between the strains tested, INPA 3-11b, UFLA 3-84, BR 3267, BR 3262 and BR 3299, presenting values similar to control with nitrogen fertilizer. Costa et al. (2011) also found no differences of $\mathrm{N}$ accumulation between inoculated plants, but these values were lower than control.

In the second evaluation at harvest, significant effect was observed forms of $\mathrm{N}$ supply relative to NPPL, BPPL, NAG and GY (Table 3). Among the strains, the INPA 3-11B stood out for presenting the best results both NPPL as BPPL, not differing significantly from the control with nitrogen. For variable BPPL strain in testing UFLA 3-164 showed results similar to strains INPA 3-11B and UFLA 3-84 and N-control. 
Table 2. Accumulation of nitrogen $(\mathrm{N})$, phosphorus $(\mathrm{P})$, potassium $(\mathrm{k})$, calcium $(\mathrm{Ca})$ and $\mathrm{Mg}(\mathrm{Mg})$ in shoots of Vigna unguiculata (L.) Walp, for different forms of $\mathrm{N}$ supply at flowering (45 days after seeding)

\begin{tabular}{|c|c|c|c|c|c|}
\hline \multirow{3}{*}{$\mathrm{N}$ sources } & \multicolumn{5}{|c|}{ Macronutrients accumulation } \\
\hline & $\mathrm{N}$ & $\mathrm{P}$ & $\mathrm{K}$ & $\mathrm{Ca}$ & $\mathrm{Mg}$ \\
\hline & \multicolumn{5}{|c|}{ mg plant $^{-1}$} \\
\hline TEST CN- $70 \mathrm{~kg} \mathrm{ha}^{-1}$ & $440.0100 \mathrm{a}$ & $41.025 \mathrm{a}$ & $126.350 \mathrm{ab}$ & $84.575 \mathrm{a}$ & $39.025 \mathrm{a}$ \\
\hline TEST SN & $245.500 \mathrm{bc}$ & $24.600 \mathrm{~b}$ & $69.500 \mathrm{bc}$ & $61.175 \mathrm{a}$ & $13.200 \mathrm{ab}$ \\
\hline UFLA 3-84 & $266.100 \mathrm{bc}$ & $22.800 \mathrm{~b}$ & $86.350 \mathrm{abc}$ & $41.850 \mathrm{a}$ & $19.650 \mathrm{ab}$ \\
\hline BR 3262 & $212.700 \mathrm{c}$ & $20.700 \mathrm{~b}$ & $59.830 \mathrm{c}$ & $54.450 \mathrm{a}$ & $5.800 \mathrm{~b}$ \\
\hline UFLA 3-164 & $387.050 \mathrm{ab}$ & $36.525 \mathrm{ab}$ & $113.775 \mathrm{abc}$ & $72.850 \mathrm{a}$ & $31.025 \mathrm{ab}$ \\
\hline UFLA 3-154 & $279.465 b c$ & $25.725 \mathrm{ab}$ & $93.125 \mathrm{abc}$ & $52.025 \mathrm{a}$ & $21.725 \mathrm{ab}$ \\
\hline BR 3267 & $368.075 \mathrm{ab}$ & $33.250 \mathrm{ab}$ & $136.200 \mathrm{bc}$ & $61.900 \mathrm{a}$ & $23.350 \mathrm{ab}$ \\
\hline INPA 3-11B & $325.800 \mathrm{abc}$ & $35.650 \mathrm{ab}$ & $88.325 \mathrm{abc}$ & $73.875 \mathrm{a}$ & $13.500 \mathrm{ab}$ \\
\hline \multicolumn{6}{|l|}{ Variation Sources } \\
\hline F value & $6.125^{*}$ & $4.851^{*}$ & $3.893 *$ & $1.711^{\mathrm{ns}}$ & $2.724 *$ \\
\hline Treatment (DF) & 7 & 7 & 7 & 7 & 7 \\
\hline Block (DF) & 3 & 3 & 3 & 3 & 3 \\
\hline Error (DF) & 21 & 21 & 21 & 21 & 21 \\
\hline QMR & 0.004 & 0.001 & 0.0007 & 0.004 & 0.0001 \\
\hline LSD & 0.140 & 0.009 & 0.037 & 0.049 & 0.0302 \\
\hline \multicolumn{6}{|l|}{ DMS } \\
\hline CV $(\%)$ & 20.00 & 22.64 & 28.08 & 33.49 & 61.03 \\
\hline
\end{tabular}

* Significant $5 \%$ probability by Tukey test, $\mathrm{DF}=$ degree of freedom, mean square residual $=\mathrm{QMR}, \mathrm{LSD}=$ least significant difference, $\mathrm{CV}=$ coefficient of variation. Means followed by the same letter in columns do not differ according to the Tukey test at $5 \%$ probability.

Table 3. Average number of pods per plant (NPPL), biomass of pods per plant (BPPL), nitrogen accumulation of grains (NAG) and grain yield (GY) (13\% wet basis) of Vigna unguiculata (L .) Walp, due to different forms of N supply at harvest

\begin{tabular}{|c|c|c|c|c|}
\hline \multirow{2}{*}{ N sources } & NPPL & BPPL & NAG & GY \\
\hline & Pods plant $^{-1}$ & kg plant $^{-1}$ & g plant $^{-1}$ & $\mathrm{~kg} \mathrm{ha}^{-1}$ \\
\hline TEST CN-70 kg ha-1 & $8.60 \mathrm{a}$ & $0.047 \mathrm{a}$ & $3.08 \mathrm{ab}$ & $633.606 a$ \\
\hline TEST SN & $4.425 \mathrm{c}$ & $0.03 b c$ & $1.59 \mathrm{c}$ & $319.20 \mathrm{c}$ \\
\hline UFLA 3-84 & $5.45 \mathrm{bc}$ & $0.04 \mathrm{ab}$ & $2.36 \mathrm{bc}$ & $521.11 \mathrm{~b}$ \\
\hline BR 3262 & $5.05 \mathrm{bc}$ & $0.014 \mathrm{c}$ & $3.40 \mathrm{a}$ & $636.15 \mathrm{a}$ \\
\hline UFLA 3-164 & $5.55 \mathrm{bc}$ & $0.037 \mathrm{a}$ & $2.37 \mathrm{bc}$ & $501.01 \mathrm{~b}$ \\
\hline UFLA 3-154 & $6.20 \mathrm{~b}$ & $0.017 \mathrm{c}$ & $2.81 \mathrm{ab}$ & $600.18 \mathrm{ab}$ \\
\hline BR 3267 & $6.45 b$ & $0.015 \mathrm{c}$ & $2.98 \mathrm{ab}$ & $582.83 \mathrm{ab}$ \\
\hline INPA 3-11B & $8.60 \mathrm{a}$ & $0.040 \mathrm{a}$ & $2.43 b c$ & $501.09 \mathrm{~b}$ \\
\hline \multicolumn{5}{|l|}{ Variation Sources } \\
\hline F value & $17.316^{*}$ & $17.350^{*}$ & $8.522 *$ & $21.920^{*}$ \\
\hline Treatment (DF) & 7 & 7 & 7 & 7 \\
\hline Block (DF) & 3 & 3 & 3 & 3 \\
\hline Error (DF) & 21 & 21 & 21 & 21 \\
\hline QMR & 102.06 & 0.000037 & 0.147 & 1969.19 \\
\hline LSD & 23.96 & 0.014 & 0.9106 & 105.28 \\
\hline \multicolumn{5}{|l|}{ DMS } \\
\hline CV $(\%)$ & 14.37 & 21.52 & 14.59 & 8.27 \\
\hline
\end{tabular}

* Significant $5 \%$ probability by Tukey test, $\mathrm{DF}=$ degree of freedom, mean square residual $=$ QMR, LSD $=$ least significant difference, $\mathrm{CV}=$ coefficient of variation. Means followed by the same letter in columns do not differ according to the Tukey test at $5 \%$ probability. 
With respect to the NAG inoculated treatments showed similar results to the control with $\mathrm{N}$ fertilizer.

The GY treatments inoculated ranged from 501.01 to $603.15 \mathrm{~kg} \mathrm{ha}^{-1}$ inoculated with strains BR 3-164 and BR 3262 , respectively. It should be noted that GY was higher than the regional average in these conditions $180 \mathrm{~kg} \mathrm{ha}^{-1}$ (Freire et al., 2005). Strains under selection (UFLA 3-164 and UFLA 3-154) showed GY similar results, but the UFLA 3-154 strain obtained productivity equivalent to $\mathrm{N}$-control without $\mathrm{N}$, and all the strains tested.

Inoculation of cowpea with strain BR 3262 enabled a significant GY, promoting an increase of $50.17 \%$ compared to untreated mineral $\mathrm{N}$ without inoculation and which justifies the use of this biotechnology, as well as presenting increases in production, also reduces spending, since the cost of inoculation is much smaller than in systems that adopts the use of nitrogen fertilizers. Similar results were found by Zilli et al. (2009) for work conducted under field conditions observed that strain BR 3262 proved to be the most suitable for the inoculation of cowpea seeds in State of Roraima, Brazil, seen that provided grain yield (the overall mean of about $1700 \mathrm{~kg} \mathrm{ha}^{-1}$ ) equal dose of 50 $\mathrm{kg} \mathrm{ha}^{-1}$. It is noteworthy that this productivity was achieved because these authors used fertilizer phosphorus, potassium and micronutrients in their experiments.

What can be observed in this study was that productivity almost doubled with the inoculation strain BR 3262, becoming a viable alternative for small farmers of cowpea of municipal district Itaueira-PI, as already discussed by Sousa and Smith (2011), in municipal district Confresa, State of Mato Grosso, Brazil, where the strain INPA 3-11B promoted more than $40 \% \mathrm{GY}$ relative to untreated mineral $\mathrm{N}$ and the witness similar nitrogen $(70 \mathrm{~kg} \mathrm{~N}$ $\left.\mathrm{ha}^{-1}\right)$.

Considering only the increase of GY of cowpea, compared to the control without $\mathrm{N}$ was reached higher average value of $317 \mathrm{~kg} \mathrm{ha}^{-1}$ for inoculated with strain BR 3262 and $314.4 \mathrm{~kg} \mathrm{ha}^{-1}$ for the treatment with $\mathrm{N}$ fertilizer. For treatment with fertilizer nitrogen, gross profit increase can come about $\mathrm{R} \$ 1,572.03$, an amount obtained by multiplying $314.4 \mathrm{~kg}$ of cowpea for $\$ 5.00$ (average price / $\mathrm{kg}$ grain in local markets). Subtracting the amount spent on urea $\left(159 \mathrm{~kg} \mathrm{ha}^{-1}\right)$ for the supply of $70 \mathrm{~kg} \mathrm{~N} \mathrm{ha}^{-1}$ to $\$ 3 / \mathrm{kg}$ fertilizer (average value of the fertilizer Itaueira), cost U.S.\$ 477.00 , the gain equity is R $\$ 1,095.03$. With the inoculant, multiplying $314.4 \mathrm{~kg}$ of cowpea for $\$ 5.00$, get the gain of $\mathrm{R} \$ 1,584.75$. Following the reasoning by subtracting the value of $\$ 25.00$ (price plus the shipping inoculant dose until the region), achieves U.S.\$1,559.75 profit. Therefore, there is getting treatment inoculated with a profit higher than the nitrogen treatment promoted by $\mathrm{R} \$ 464.72 \mathrm{ha}^{-1}$ which promoted significant economic advantage to the producer in relation to nitrogen fertilization.

\section{Conclusions}

1). The strains in the test phase (UFLA 3-154 and UFLA 3-164) present nodule number and fresh and dry biomass of nodules similar to strains currently approved as inoculant.

2). Treatments inoculated with strains INPA 3-11B e BR 3267 were more efficient in the production of dry biomass of shoots.

3). Plants inoculated with the strains UFLA 3-164, INPA 3-11B and BR 3267 presented the highest concentrations of $\mathrm{N}, \mathrm{P}, \mathrm{K}, \mathrm{Ca}$, and $\mathrm{Mg}$ in the dry biomass of shoots.

4). The strains in process of selection (UFLA 3-164 and UFLA 3-154) showed similar results to grain yield, but the UFLA 3-154 strain obtained productivity equivalent to the control with use nitrogen fertilizer, and all other strains tested.

5). Inoculation of cowpea promotes increase grain yield on family farms in State of Piauí, Brazil.

6). Strains BR 3262, BR 3267, UFLA 3-154 and INPA 3-11B showed similar yield to witness that received nitrogen fertilization may be recommended for cultivation in this region.

\section{Acknowledgements}

The authors thank the Conselho Nacional de Desenvolvimento Científico e Tecnológico (CNPq), Ministério da Agricultura Pecuária e Abastecimento (MAPA) e Secretaria de Desenvolvimento da Agricultura/SDA for financial assistance to the project. At the Programa Nacional de Cooperação Acadêmica (PROCAD) that enabled the exchange with the Federal University of Lavras (UFLA), Department of Soil Science (DCS). To CNPq for scholarship research productivity for F.M.S. Moreira.

\section{References}

Almeida, A. L. G., Alcântara, R. M. C. M., Nóbrega, R. S. A., Leite, L. F. C., Silva, J. A. L., \& Nóbrega, J. C. A. (2010). Produtividade do feijão caupi cv. BR 17 Gurguéia inoculado com bactérias diazotróficas simbióticas 
no Piauí. Revista Brasileira de Ciências Agrárias, 5, 364-36. Retrieved from http://redalyc.uaemex.mx/src/inicio/ArtPdfRed.jsp?iCve=119016971014

Calvache, A. M., \& Reichardt, K. (1996). Efeito de épocas de deficiência hídrica na eficiência do uso do nitrogênio da cultura do feijão cv. Imbabello. Scientia agrícola, 53, 2-3. http://dx.doi.org/10.1590/S0103-90161996000200025

Costa, E. M., Nóbrega, R. S. A., Martins, L. V., Amaral, F. H. C., \& Moreira, F. M. S. (2011). Nodulação e produtividade de Vignaunguiculata (L.) Walp. por cepas de rizóbio em Bom Jesus, PI. Revista Ciência Agronômica, 42, 1-7. http://dx.doi.org/10.1590/S1806-66902011000100001

Ferreira, D. F. (2000). Análises estatísticas por meio do Sisvar para Windows 4.0. In Reunião Anual Brasileira da Sociedade Internacional de Biometria, 45. São Carlos. Anais... São Carlos: Universidade Federal de São Carlos (pp. 255-258).

Freire Filho, F. R., Benvindo, R. N., Almeida, A. L. G., Oliveira, J. T. S., \& Portela, G. L. F. (2007). Caracterização de pólos de produção da cultura de feijão caupi no estado o Piauí. Embrapa Meio Norte, p. 28 (Documento, 100).

Freire Filho, F. R., Lima, J. A. A., \& Ribeiro, V. Q. (2005). Feijão caupi: avanços tecnológicos. Brasília, DF: Embrapa Informações tecnológicas (p. 519).

Guedes, G. N., Souza, A. dos S., \& Alves, L. de S. (2010). Eficiência agronômica de inoculantes em feijãocaupi no município de Pombal - PB. Revista Verde de Agroecologia e Desenvolvimento Sustentável, 5, 82-96.

Guimarães, A., Jaramillo, P., NÓBREGA, R. S. A., Florentino, L. A., Silva, K., \& Moreira, F. M. S. (2012). Genetic and symbiotic diversity of nitrogen-fixing bacteria isolated from soils under agriculture use in the Western Amazon using cowpea as the trap plant. Applied and Environmental Microbiology (Print), 78, 6726-6733. http://dx.doi.org/10.1128/AEM.01303-12

Instituto Brasileiro de Geografia e Estatística (IBGE). (2006). Levantamento sistemático da produção agrícola: relatório geral: culturas temporárias da região nordeste. Retrieved from http://www.ibge.gov.br/home/estatistica/indicadores/agropecuaria/Ispa/defalt.shtm

Lacerda, A. M., Moreira, F. M. S., Andrade, M. J. B., \& Soares, A. L. L. (2004). Efeito de estirpes de rizóbio sobre a nodulação e produtividade do feijão caupi. Revista Ceres, 51, 67-82.

Liao, C. F. H. (1981). Devarda's allow methods for total nitrogen determination. Soil Science Society of America Journal, 45, 852-855. http://dx.doi.org/10.2136/sssaj1981.03615995004500050005x

Lima, A. S., Perreira, J. P. A. R., \& Moreira, F. M. S. (2005). Diversidade fenotípica e eficiência simbiótica de estirpes de Bradyrhizobium spp. de solos da Amazônia. Pesquisa Agropecuária Brasileira, 40, 1095-1104. http://dx.doi.org/10.1590/S0100-204X2005001100007

Malavolta, E., Vitti, G. C., \& Oliveira, S. A. (1997). Avaliação do estado nutricional das plantas: princípio e aplicações. Piracicaba: Potafós (p. 319).

Martins, L. M. V., Xavier, G. R., Rangel, F. W., Ribeiro, J. R. A., Neves, M. C. P., Morgado, L. B., \& Rumajanek, N. G. (2003). Contribution of biological nitrogen fixation to cowpea: a strategy for improving yield in the Semi-Arid region of Brazil. Biology and Fertility of Soils, 38, 333-339. http://dx.doi.org/10.1007/s00374-003-0668.

Martins, R. N., Nóbrega, R. S. A., Silva, A. F. T., Amaral, F. H. C., Costa, E. M., Lustosa Filho, J. F., \& Martins, L. V. (in press). Nitrogênio e micronutrientes na produção de grãos de feijão caupi inoculado. Semina. Ciências Agrárias.

Melloni, R., Moreira, F. M. S., Nóbrega, R. S. A., \& Siqueira, J. O. (2006). Eficiência e diversidade fenotípica de bactérias diazotróficas que nodulamcaupi (Vigna unguiculata L. Walp) e Feijoeiro (Phaseolus vulgaris L.) em Solos de Mineração de Bauxita em Reabilitação. Revista Brasileira de Ciência do Solo, 20, $235-246$. http://dx.doi.org/10.1590/S0100-06832006000200005

Motta, J. S. (2002). Diversidade fenotípica e eficiência simbiótica de cepas de Bradyrhizobiumsp. isoladas de áreas de mineração de bauxita reabilitadas. Dissertação (Mestrado em Solos e Nutrição de Plantas) Universidade Federal de Lavras, Lavras.

Soares, A. L. L., Pereira, J. P. A. R., Ferreira, P. A. A., Vale, H. M. M., Lima, A. S., Andrade, M. J. B., \& Moreira, F. M. S. (2006). Eficiência agronômica de rizóbios selecionados e diversidade de populações nativas 
nodulíferas em Perdões (MG). I - caupi. Revista Brasileira de Ciência do Solo, 30, 795-802. http://dx.doi.org/10.1590/S0100-06832006000500006

Sousa, P. M., \& Moreira, F. M. S. (2009). Potencial econômico de rizóbios em feijão caupi na agricultura familiar: um estudo de caso. Extensão rural, 10, 37-54.

Waksman, S. A., \& Fred, E. B. (1928). Laboratory manual of general microbiology. New York: McGraw-Hill Book Company (p. 143).

Zilli, J. E., Marson, L. C., Marson, B. F., Rumjanek, N. G., \& Xavier, G. R. (2009). Contribuição de estirpes de rizóbio para o desenvolvimento e produtividade de grãos de feijão caupi em Roraima. Acta Amazônica, 39, 749-758. http://dx.doi.org/10.1590/S0044-59672009000400003 